\title{
Methane-producing human subjects have higher serum glucose levels during oral glucose challenge than non-methane producers: a pilot study of the effects of enteric methanogens on glycemic regulation
}

\author{
Ruchi Mathur ${ }^{1 *}$, Deepinder Goyal ${ }^{2}$, Gene Kim², Gillian M. Barlow², Kathleen S. Chua ${ }^{2}$ and Mark Pimentel ${ }^{2}$ \\ *Correspondence: Ruchi.Mathur@cshs.org

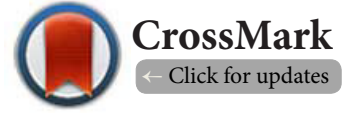 \\ 'Division of Endocrine Diabetes and Metabolism, Department of Medicine, Cedars-Sinai Medical Center, Los Angeles, California, USA. \\ ${ }^{2} \mathrm{GI}$ Motility Program, Cedars Sinai Medical Center, UCLA School of Medicine, Los Angeles, California, USA.
}

\begin{abstract}
Background: Recent studies support that intestinal microbes contribute to human disease, and enteric methanogens have been specifically linked to altered gut metabolism and weight gain. In this study, we tested whether methane on breath test (as a surrogate for colonization with the predominant methanogen Methanobrevibacter smithii) is associated with altered glucose tolerance in humans.

Methods: Consecutive methane producing (methane $\geq 3 \mathrm{ppm}, \mathrm{N}=5$ ) and non-methane producing (methane $<3 \mathrm{ppm}, \mathrm{N}=15)$ subjects undergoing lactulose breath test at our center were recruited and subjected to a $75 \mathrm{~g}$ oral glucose tolerance test (OGTT).

$\underline{\text { Results: }}$ The average age of methane-producing subjects was $48.8 \pm 10.0$ vs. $37.7 \pm 12.1$ for non-methane subjects $(\mathrm{P}=0.17)$. Methane and non-methane subjects also had comparable mean body mass index (BMI) (23.9 $\pm 0.2 \mathrm{vs.} 25.0 \pm 8.0 \mathrm{~kg} / \mathrm{m} 2 ; \mathrm{P}=0.53)$ and baseline insulin resistance (HOMA-IR) (1.32 \pm 0.72 vs. $2.21 \pm 1.52$; $\mathrm{P}=0.23)$. During 180 minutes post-glucose load, methane producers had greater serum glucose area-under-the-curve (AUC) $(774.2 \pm 140.3 \mathrm{mg} / \mathrm{dL})$ than non-methane subjects $(585.5 \pm 128.3 \mathrm{mg} / \mathrm{dL})(\mathrm{P}=0.03)$, but similar insulin AUC (217.76 $\pm 122.08 \mu \mathrm{U} / \mathrm{mL}$ vs. $215.37 \pm 75.02 \mu \mathrm{U} / \mathrm{mL}$, respectively).

Conclusions: Individuals with methane on breath test (reflecting higher colonization with enteric methanogens, predominantly M. smithii) may have impaired glucose tolerance when challenged with a high carbohydrate load, and may also have a higher susceptibility to hyperglycemia which appears to be independent of basal insulin resistance and BMI.
\end{abstract}

Keywords: Methanogens, hyperglycemia, diabetes mellitus, insulin resistance

\section{Introduction}

In last decade, important metabolic functions have been identified for gut microbes. Evidence from animal models suggests roles for gut microbes and gut-derived metabolic endotoxemia in fat accumulation, nonalcoholic steatohepatitis (NASH), and the development of type 2 diabetes mellitus [1-5]. Moreover, modulation of gut microbial populations using non-absorbable antibiotics improves fasting and oral glucose tolerance in diet-induced obese and insulin-resistant mice [6], and in mice fed a high-fat diet, antibiotic treatment ameliorates metabolic endotoxinemia and cecal lipopolysaccharide, which correlates with impaired glucose tolerance and body weight $[2,7]$.

In humans, the intestinal tract is host to $10^{14}$ microbes from approximately 1000 species that include bacteria, archaea, and eukaryotes, which contribute to human health through roles in host metabolism and energy homeostasis, including breaking down non-digestible foods for absorption, energy harvest, and vitamin synthesis [8-10]. Methanogens are important constituents of the human gut microbiota. This distinct group grows primarily under anaerobic conditions [11], and produces methane $\left(\mathrm{CH}_{4}\right)$ as a byproduct of fermentation [12-14]. Methanogens are unique in that their metabolism increases in the presence of products from other bacteria [15], as they scavenge hydrogen and ammonia from other bacteria as substrates for the generation of methane [12-16]. Once absorbed into the systemic circulation, methane is cleared via the lungs and can be quantitated by breath testing. The majority of methanogens colonizing the human gut are from the genus Methanobrevibacter; predominantly M. smithii [17-19]. While M. smithii is found in the isolated portion of the lower GI tract of $70 \%$ of unselected "normal" subjects, due to the threshold required for detection in the breath, only $15 \%$ of the population has methane on breath test ( $\geq 3 \mathrm{ppm})[20,21]$, and we have previously shown that methane on breath test correlates with higher levels of M. smithii in stool [22].

In humans, breath methane has been associated with constipation: we found that subjects with IBS who have methane on breath test were almost universally constipated [20], and 
subsequent studies showed methane to be predictive of constipation among functional bowel disease patients [23] as well as in IBS and non-IBS subjects [24]. In a meta-analysis of 1277 IBS patients, we found that methane was associated with constipation, with a pooled $\mathrm{OR}=3.51(\mathrm{Cl}=2.00-6.16)$ [25]. Further, treatment with the non-absorbable antibiotics neomycin and rifaximin both eliminates methane and improves constipation [26], particularly in C-IBS subjects with successful eradication of methane on breath test (Pimentel et al., submitted), suggesting that methane itself is the cause of the constipation. Methanogens have been shown to facilitate increased fermentation of dietary polysaccharides by other microbes, resulting in increased short-chain fatty acid (SCFA) production and enhanced availability of calories to the host [27-29]. In two separate human studies, our group has now shown that the presence of both methane and hydrogen on breath test is associated with greater body mass index (BMI) $[30,31]$ and percent body fat [31]. To further characterize the effects of methanogenic colonization on metabolic parameters, we examined whether elevated breath methane is associated with changes in glucose tolerance in humans.

\section{Materials and methods}

This study was approved by our institutional review board and informed consent was obtained from all patients. Consecutive adult subjects undergoing lactulose breath testing at a tertiary care medical center were recruited. A total of 20 subjects were administered $10 \mathrm{gm}$ oral lactulose load after a baseline breath sample. Lactulose is a polysaccharide that is not digested by humans, but can be utilized by enteric flora. Repeat breath samples were then obtained 15 minutes after lactulose ingestion, and levels of methane and hydrogen were analyzed using gas chromatography (Quintron instrument company, Milwawkee, WI). A positive methane breath test was defined as a breath methane level $\geq 3$ parts per million (ppm) as previously published $[20,23]$. Of these subjects, 15 non-methane and 5 methane positive subjects were consented to undergo an oral glucose tolerance test (OGTT). BMI was not a criterion for recruitment. All subjects underwent a standard $75 \mathrm{~g}$ OGTT with venous sampling for glucose and insulin levels at baseline and every 30 minutes for 3 hours post-ingestion. The homeostasis model assessment of insulin resistance (HOMA-IR) was used to quantify insulin resistance and beta-cell function, according to the formula: glucose $(\mathrm{mg} / \mathrm{dL})$ x insulin $(\mu \mathrm{U} / \mathrm{mL}) / 405$. Mann Whitney $\mathrm{U}$ test was utilized for non-parametric data and student's t-test was used for normally distributed data. All tests were two-tailed and statistical significance was defined as $\mathrm{P}<0.05$.

\section{Results \\ Study subjects}

A total of 20 subjects were recruited for this study (15 nonmethane producing and 5 methane-producing). The average age of non-methane producing subjects was $37.7 \pm 12.1$ years, vs. $48.8 \pm 10.0$ years for methane subjects $(P=0.17)$ (Table 1 ). The mean BMI in the non-methane group was $25.0 \pm 8.0 \mathrm{~kg} / \mathrm{m}^{2}$, which was not statistically different from that in the methane group, $23.9 \pm 0.2 \mathrm{~kg} / \mathrm{m}^{2}(P=0.53)$. Basal HOMA-IR levels were also comparable for the non-methane (2.21 \pm 1.52$)$ and methane (1.32 \pm 0.72$)$ groups $(P=0.23)$, as were fasting blood glucose levels $(80.26 \pm 8.1 \mathrm{mg} / \mathrm{dL}$ vs. $77.6 \pm 14.5 \mathrm{mg} / \mathrm{dL}, \mathrm{P}=0.06)$ and fasting insulin levels $(11.06 \pm 7.44 \mu \mathrm{U} / \mathrm{ml}$ vs. $7.16 \pm 3.85 \mu \mathrm{U} / \mathrm{ml}$, $\mathrm{P}=0.28)($ Table 1).

Table 1. Comparison of methane producers $(n=5)$ versus non-methane producers $(n=15)($ mean $\pm S D)$.

\begin{tabular}{llll}
\hline Parameters & $\begin{array}{l}\text { Methane positive } \\
\text { subjects } \mathbf{N = 5}\end{array}$ & $\begin{array}{l}\text { Non-methane } \\
\text { subjects } \mathbf{N}=\mathbf{1 5}\end{array}$ & P value $^{*}$ \\
\hline Age $(\mathrm{yrs})$ & $48.8 \pm 10.0$ & $37.7 \pm 12.1$ & $\mathrm{P}=0.17$ \\
$\mathrm{BMI}^{\dagger}\left(\mathrm{kg} / \mathrm{m}^{2}\right)$ & $23.9 \pm 0.2$ & $25.0 \pm 8.0$ & $\mathrm{P}=0.53$ \\
$\begin{array}{l}\text { Fasting blood glucose } \\
(\mathrm{mg} / \mathrm{dL})\end{array}$ & $77.6 \pm 14.5$ & $80.26 \pm 8.10$ & $\mathrm{P}=0.6$ \\
$\begin{array}{l}\text { Insulin }(\mu \mathrm{U} / \mathrm{mL}) \\
\text { Baseline HOMA-IR }\end{array}$ & $7.16 \pm 3.85$ & $11.06 \pm 7.44$ & $\mathrm{P}=0.28$ \\
$\begin{array}{l}180 \text { minutes glucose } \\
\text { AUC } \\
(\mathrm{mg} / \mathrm{dL})\end{array}$ & $774.2 \pm 140.3$ & $585.5 \pm 128.3$ & $\mathrm{P}=0.03$ \\
\hline
\end{tabular}

${ }^{*} \mathrm{P}<0.05$ considered statistically significant

${ }^{\dagger} \mathrm{BMI}$ : Body mass index

${ }^{\ddagger}$ HOMA-IR: Homeostasis model of insulin resistance

${ }^{\S}$ AUC: Area under the curve

OGTT: 75 gm Oral glucose tolerance test

Methane producers have higher glucose, but not insulin, area-under-the-curve than non-methane producers

During the 180 minutes post-glucose load (i.e., post-OGTT), methane producers had a significantly higher serum glucose area-under-the-curve (AUC) $(774.2 \pm 140.3 \mathrm{mg} / \mathrm{dL})$ than non-methane producers $(585.5 \pm 128.3 \mathrm{mg} / \mathrm{dL})(\mathrm{P}=0.03)$ (Figures $1 \mathbf{a}$ and $\mathbf{1 b}$ ). In contrast, there was no significant difference in 180 minutes insulin AUC between methane producers $(217.76 \pm 122.08 \mu \mathrm{U} / \mathrm{mL})$ and non-methane producers $(215.37 \pm 75.02 \mu \mathrm{U} / \mathrm{mL}$ ) (Figures $\mathbf{2 a}$ and $\mathbf{2 b}$ ). This resulted in a difference in glucose-to-insulin ratios post-OGTT between methane producers and non-methane producers (Figure 3 ).

\section{Discussion}

We found that methane-producing subjects have a significantly higher increase in absolute glucose levels when undergoing an oral glucose challenge than their non-methane producing counterparts. This finding was independent of BMI. Further, there was no significant difference in the insulin resistance of methane-producing subjects (as measured by HOMAIR) as compared to non-methane producers. This suggests that subjects with intestinal methane production may have impaired glucose tolerance when challenged with a high carbohydrate load, and may a higher predisposition towards the development of hyperglycemia which appears to be 


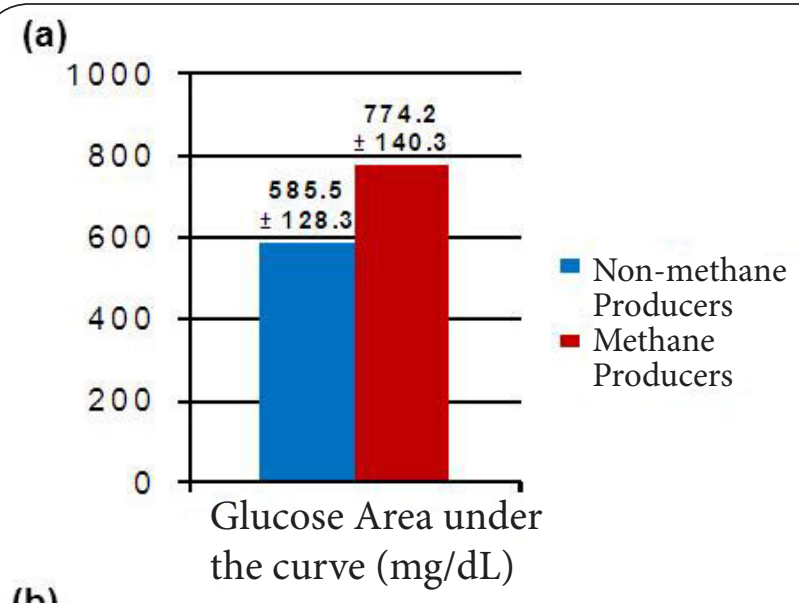

(b)

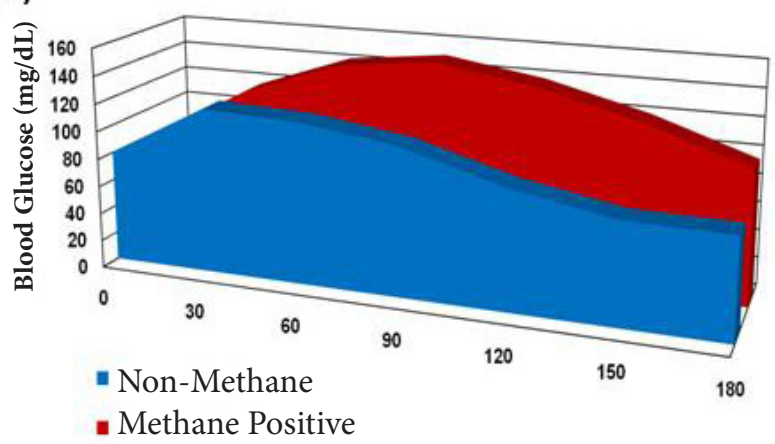

Figure 1. Methane producers had significantly higher 180 minutes serum glucose AUC then non-methane producers.

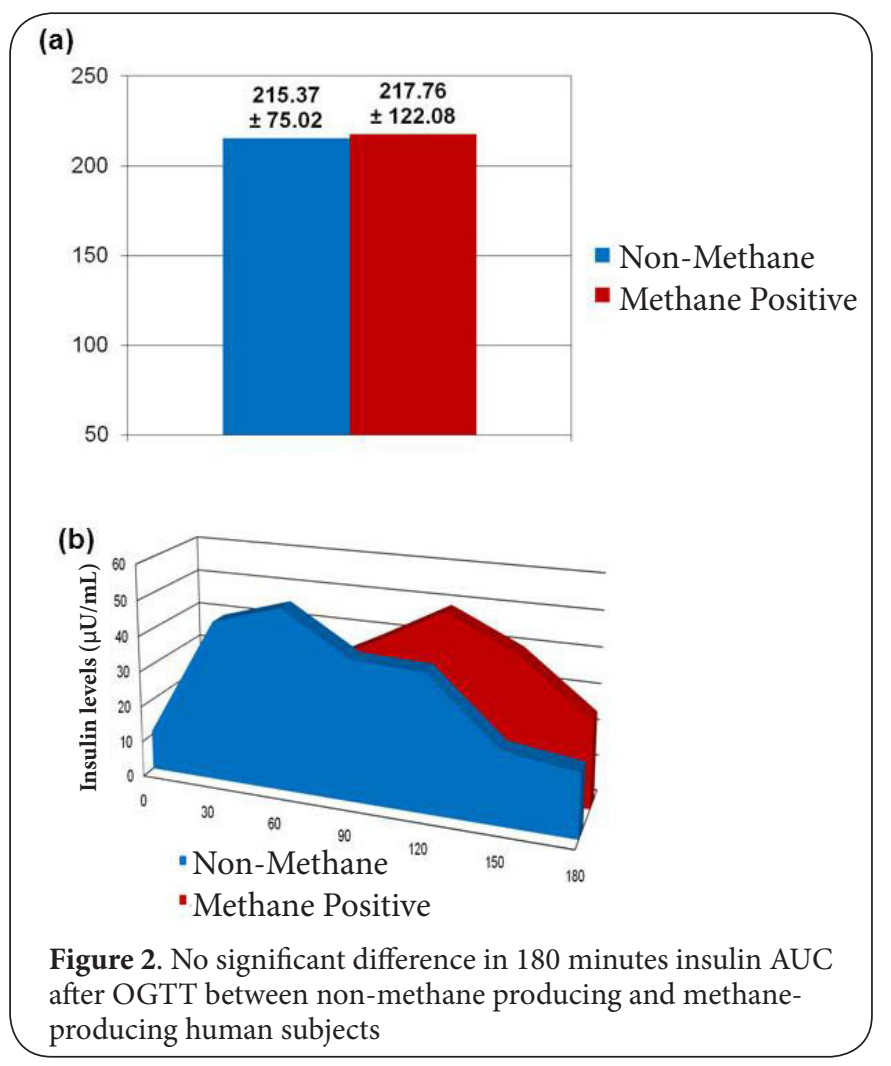

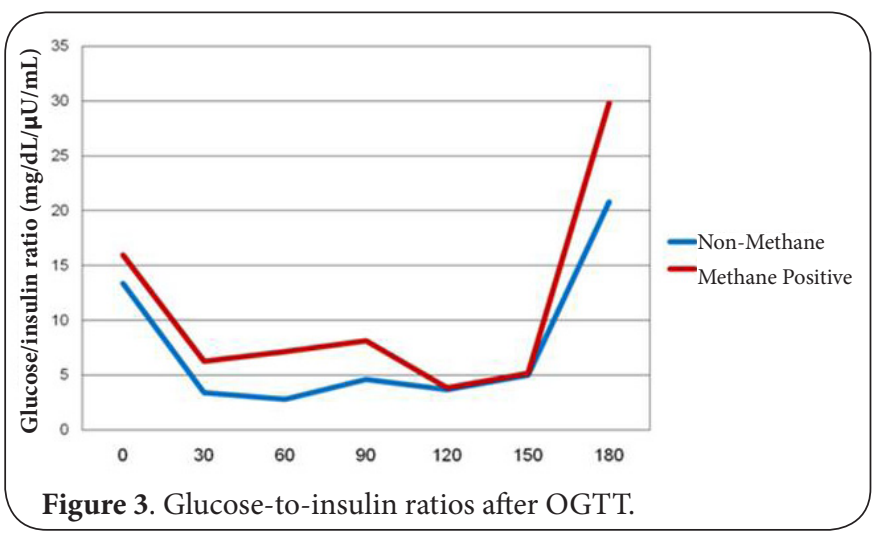

independent of basal insulin resistance and BMI.

Gut microbes contribute to human health through roles in host metabolism and energy homeostasis, including the break-down of otherwise non-digestible foods for absorption, energy harvest, and vitamin synthesis. The methanogenic archaea (methanogens) have been specifically linked to altered metabolism and weight gain in the host [11]. These anaerobic archaea utilize hydrogen and ammonia produced by other microbes as substrates for the generation of methane $[12-13,15,32]$. The predominant methanogen in the human gut is Methanobrevibacter smithii [17-19,32], and there is increasing evidence for a specific role for $M$. smithii in the development of obesity. Using a germ free animal model, introduction of a single Bacteroides species (B. thetaiotaomicron) and $M$. smithii was found to result in greater weight gain than the introduction of $B$. thetaiotaomicron alone [27]. The current hypothesis is that by scavenging hydrogen produced by syntrophic microbes for the production of methane (the "sink effect") [14], M. smithii prevents excessive build-up of $\mathrm{H}_{2^{\prime}}$ allowing for increased polysaccharide fermentation by these syntrophs, resulting in increased short-chain fatty acid (SCFA) production and enhanced availability of calories to the host $[28,29]$. Host absorption of SCFAs produced in this manner can provide up to $10 \%$ of daily caloric intake, depending on dietary content [33]. In two human studies, our group has shown that the presence of both methane and hydrogen on breath test is associated with greater body mass index (BMI) $[30,31]$ and percent body fat [31], supporting the hypothesis that increased intestinal colonization with methanogens can contribute to increased caloric uptake and weight gain in the host. Another recent study suggested a role for differences in intestinal methane production in altered glycemic control in diabetic subjects [34], further supporting our finding of altered glucose levels in methane-producing individuals, and methane producers have also been shown to have higher fasting serum cholesterol concentrations when compared to age-, sex-, and BMI-matched non-methane producers. The alteration between systemic availability of acetate and propionate produced during carbohydrate fermentation by methanogenic archaea has been suggested to influence 
the blood lipid levels [35-37]. Using an animal model and ex vivo studies, our group has also shown that methane may also directly affect intestinal transit and gut neuromuscular function [38], findings which have since been confirmed by an independent group [39]. Slower gut motility could also result in increased time for nutrient absorption and energy harvest.

Recent reports in animal models have suggested possible contributing roles of enteric microbes in insulin resistance. Gut flora-derived metabolic endotoxemia via lipopolysaccharide production has been implicated in the development of type 2 diabetes mellitus $[2,6]$. Activation of the Toll-Like Receptor 4 (TLR4) cascade signaling system by enteric lipopolysaccharide ligands is believed to be one important mediator of insulin resistance $[\mathbf{1}, \mathbf{4 0}]$. Further, gut decontamination with norfloxacin and ampicillin enhanced insulin sensitivity in mice, independent of food intake and adiposity [7]. In another study, antibiotic treatment resulted in parallel amelioration of impaired glucose tolerance and reduction of body weight in mice [2].

The present study is the first description of an association between methane production and alterations in glucose metabolism in humans. However, our study has several limitations. Methane breath testing and OGTT were performed on separate days with a maximum difference of 7 days. However, it is unlikely to alter the findings as the presence and quantity of methanogens harbored by any given individual are remarkably constant over years [11]. It is also unclear at the present time whether this is simply an association or a cause-and-effect relationship. Moreover, due to the small sample size in this study, further investigations are needed before firm conclusions can be drawn on the role of gut methanogens in development of hyperglycemia. Given the potential significance of this finding, further large scale studies are warranted to confirm the association of gut methanogens and glycemic regulation, and to elucidate potential mechanisms.

\section{Competing interests}

The authors declare that they have no competing interests.

\section{Authors' contributions}

\begin{tabular}{|l|c|c|c|c|c|c|}
\hline Authors' contributions & RM & DG & GK & GMB & KSC & MP \\
\hline Research concept and design & $\checkmark$ & -- & -- & -- & -- & $\checkmark$ \\
\hline Collection and/or assembly of data & -- & $\checkmark$ & $\checkmark$ & -- & $\checkmark$ & -- \\
\hline Data analysis and interpretation & $\checkmark$ & $\checkmark$ & -- & -- & -- & $\checkmark$ \\
\hline Writing the article & $\checkmark$ & $\checkmark$ & -- & $\checkmark$ & -- & $\checkmark$ \\
\hline Critical revision of the article & $\checkmark$ & -- & -- & $\checkmark$ & -- & $\checkmark$ \\
\hline Final approval of article & $\checkmark$ & $\checkmark$ & $\checkmark$ & $\checkmark$ & $\checkmark$ & $\checkmark$ \\
\hline Statistical analysis & -- & -- & -- & -- & -- & $\checkmark$ \\
\hline
\end{tabular}

Publication history

Senior Editor: Riccardo Pierantoni, II Universita di Napoli, Italy. Received: 10-Aug-2013 Revised: 14-Jan-2014

Accepted: 31-Jan-2014 Published: 04-Mar-2014

\section{References}

1. Abu-Shanab A and Quigley EM. The role of the gut microbiota in nonalcoholic fatty liver disease. Nat Rev Gastroenterol Hepatol. 2010; 7:691-701. | Article | PubMed

2. Cani PD, Bibiloni R, Knauf C, Waget A, Neyrinck AM, Delzenne NM and Burcelin R. Changes in gut microbiota control metabolic endotoxemiainduced inflammation in high-fat diet-induced obesity and diabetes in mice. Diabetes. 2008; 57:1470-81. | Article | PubMed

3. Sanz Y, Santacruz A and Gauffin P. Gut microbiota in obesity and metabolic disorders. Proc Nutr Soc. 2010; 69:434-41. | $\underline{\text { Article I PubMed }}$

4. Musso G, Gambino R and Cassader M. Interactions between gut microbiota and host metabolism predisposing to obesity and diabetes. Annu Rev Med. 2011; 62:361-80. | Article | PubMed

5. Cani PD and Delzenne NM. The gut microbiome as therapeutic target. Pharmacol Ther. 2011; 130:202-12. I Article I PubMed

6. Musso G, Gambino R and Cassader M. Obesity, diabetes, and gut microbiota: the hygiene hypothesis expanded? Diabetes Care. 2010; 33:2277-84. | Article | PubMed Abstract | PubMed Full Text

7. Chou CJ, Membrez M and Blancher F. Gut decontamination with norfloxacin and ampicillin enhances insulin sensitivity in mice. Nestle Nutr Workshop Ser Pediatr Program. 2008; 62:127-37. | Article | PubMed

8. Mueller K, Ash C, Pennisi E and Smith O. The gut microbiota. Introduction. Science. 2012; 336:1245. | Article | PubMed

9. Allen CA and Torres AG. Host-microbe communication within the GI tract. Adv Exp Med Biol. 2008; 635:93-101. | Article I PubMed

10. Backhed F, Ley RE, Sonnenburg JL, Peterson DA and Gordon JI. Hostbacterial mutualism in the human intestine. Science. 2005; 307:1915-20. | Article | PubMed

11. Sahakian $A B$, Jee $S R$ and Pimentel M. Methane and the gastrointestinal tract. Dig Dis Sci. 2010; 55:2135-43. | Article | PubMed

12. McKay LF, Holbrook WP and Eastwood MA. Methane and hydrogen production by human intestinal anaerobic bacteria. Acta Pathol Microbiol Immunol Scand B. 1982; 90:257-60. | Article | PubMed

13. Gibson GR, Cummings JH, Macfarlane GT, Allison C, Segal I, Vorster HH and Walker AR. Alternative pathways for hydrogen disposal during fermentation in the human colon. Gut. 1990; 31:679-83. | Article | PubMed Abstract | PubMed Full Text

14. Bauchop T and Mountfort DO. Cellulose fermentation by a rumen anaerobic fungus in both the absence and the presence of rumen methanogens. Appl Environ Microbiol. 1981; 42:1103-10. | Article | PubMed Abstract | PubMed Full Text

15. Jones WJ, Nagle DP, Jr. and Whitman WB. Methanogens and the diversity of archaebacteria. Microbiol Rev. 1987; 51:135-77. | Article I PubMed Abstract | PubMed Full Text

16. Blaut M. Metabolism of methanogens. Antonie Van Leeuwenhoek. 1994; 66:187-208. | Article | PubMed

17. Weaver GA, Krause JA, Miller TL and Wolin MJ. Incidence of methanogenic bacteria in a sigmoidoscopy population: an association of methanogenic bacteria and diverticulosis. Gut. 1986; 27:698-704. I Article I PubMed Abstract | PubMed Full Text

18. Pochart P, Lemann F, Flourie B, Pellier P, Goderel I and Rambaud JC. Pyxigraphic sampling to enumerate methanogens and anaerobes in the right colon of healthy humans. Gastroenterology. 1993; 105:1281-5. | Article I PubMed

19. Miller TL and Wolin MJ. Enumeration of Methanobrevibacter smithii in human feces. Arch Microbiol. 1982; 131:14-8. | Article I PubMed

20. Pimentel M, Mayer AG, Park S, Chow EJ, Hasan A and Kong Y. Methane production during lactulose breath test is associated with gastrointestinal disease presentation. Dig Dis Sci. 2003; 48:86-92. | PubMed

21. Pimentel M, Chow EJ and Lin HC. Normalization of lactulose breath testing correlates with symptom improvement in irritable bowel syndrome. a double-blind, randomized, placebo-controlled study. Am J 
Mathur et al. Research Journal of Endocrinology and Metabolism 2014, http://www.hoajonline.com/journals/pdf/2053-3640-2-2.pdf

Gastroenterol. 2003; 98:412-9. | Article | PubMed

22. Kim G, Deepinder F, Morales W, Hwang L, Weitsman S, Chang C, Gunsalus $\mathrm{R}$ and Pimentel $\mathrm{M}$. Methanobrevibacter smithii is the predominant methanogen in patients with constipation-predominant IBS and methane on breath. Dig Dis Sci. 2012; 57:3213-8. | Article | PubMed

23. Chatterjee $S$, Park $S$, Low $K$, Kong $Y$ and Pimentel $M$. The degree of breath methane production in IBS correlates with the severity of constipation. Am J Gastroenterol. 2007; 102:837-41. | Article | PubMed

24. Attaluri A, Jackson M, Valestin $J$ and Rao SS. Methanogenic flora is associated with altered colonic transit but not stool characteristics in constipation without IBS. Am J Gastroenterol. 2010; 105:1407-11. | Article | PubMed Abstract | PubMed Full Text

25. Kunkel D, Basseri RJ, Makhani MD, Chong K, Chang C and Pimentel M. Methane on breath testing is associated with constipation: a systematic review and meta-analysis. Dig Dis Sci. 2011; 56:1612-8. | Article | PubMed

26. Pimentel M, Chatterjee S, Chow EJ, Park S and Kong Y. Neomycin improves constipation-predominant irritable bowel syndrome in a fashion that is dependent on the presence of methane gas: subanalysis of a double-blind randomized controlled study. Dig Dis Sci. 2006; 51:1297-301. | Article | PubMed

27. Samuel BS and Gordon JI. A humanized gnotobiotic mouse model of host-archaeal-bacterial mutualism. Proc Natl Acad Sci U S A. 2006; 103:10011-6. | Article | PubMed Abstract | PubMed Full Text

28. Samuel BS, Hansen EE, Manchester JK, Coutinho PM, Henrissat B, Fulton R, Latreille P, Kim K, Wilson RK and Gordon JI. Genomic and metabolic adaptations of Methanobrevibacter smithii to the human gut. Proc Natl Acad Sci U S A. 2007; 104:10643-8. | Article | PubMed Abstract | PubMed Full Text

29. Schink B. Energetics of syntrophic cooperation in methanogenic degradation. Microbiol Mol Biol Rev. 1997; 61:262-80. | Article | PubMed Abstract | PubMed Full Text

30. Basseri RJ, Basseri B, Pimentel M, Chong K, Youdim A, Low K, Hwang L, Soffer $\mathrm{E}$, Chang $\mathrm{C}$ and Mathur R. Intestinal methane production in obese individuals is associated with a higher body mass index. Gastroenterol Hepatol (N Y). 2012; 8:22-8. | PubMed Abstract | PubMed Full Text

31. Mathur R, Amichai M, Chua KS, Mirocha J, Barlow GM and Pimentel M. Methane and hydrogen positivity on breath test is associated with greater body mass index and body fat. J Clin Endocrinol Metab. 2013; 98:E698-702. | Article | PubMed

32. de Lacy Costello BP, Ledochowski M and Ratcliffe NM. The importance of methane breath testing: a review. J Breath Res. 2013; 7:024001. | Article I PubMed

33. McNeil NI. The contribution of the large intestine to energy supplies in man. Am J Clin Nutr. 1984; 39:338-42. | Article | PubMed

34. Cesario V, Di Rienzo TA and Pitocco D et al. Diabetes and Gastrointestinal Disorders: The Effect of Intestinal Methane Production on Glycemic Control. Gastroenterology. 2013; 144:S-564.

35. Wolever TM, Fernandes J, Rao VA, Chiasson JL, Josse RG and Leiter LA. Positive methane-producing status associated with increased serum cholesterol in subjects with impaired glucose tolerance. Diabetes Care. 1995; 18:1010-2. | Article | PubMed

36. Nishina PM and Freedland RA. Effects of propionate on lipid biosynthesis in isolated rat hepatocytes. J Nutr. 1990; 120:668-73. Article I PubMed

37. Chen $\mathrm{M}$ and Wolin MJ. Influence of $\mathrm{CH} 4$ production by Methanobacterium ruminantium on the fermentation of glucose and lactate by Selenomonas ruminantium. Appl Environ Microbiol. 1977; 34:756-9. | Article | PubMed Abstract | PubMed Full Text

38. Pimentel $M$, Lin HC, Enayati P, van den Burg B, Lee HR, Chen JH, Park $\mathrm{S}$, Kong $\mathrm{Y}$ and Conklin J. Methane, a gas produced by enteric bacteria, slows intestinal transit and augments small intestinal contractile activity. Am J Physiol Gastrointest Liver Physiol. 2006; 290:G1089-95. | Article | PubMed

39. Jahng J, Jung IS, Choi EJ, Conklin JL and Park $\mathrm{H}$. The effects of methane and hydrogen gases produced by enteric bacteria on ileal motility and colonic transit time. Neurogastroenterol Motil. 2012; 24:185-90, e92. | Article | PubMed

40. Kim JJ and Sears DD. TLR4 and Insulin Resistance. Gastroenterol Res Pract. 2010; 2010. | Article | PubMed Abstract | PubMed Full Text

\section{Citation:}

Mathur R, Goyal D, Kim G, Barlow GM, Chua KS and Pimentel M. Methane-producing human subjects have higher serum glucose levels during oral glucose challenge than non-methane producers: a pilot study of the effects of enteric methanogens on glycemic regulation. Res J Endocrinol Metab. 2014; 2:2. http://dx.doi.org/10.7243/2053-3640-2-2 